\title{
Land Suitability Evaluation For Horticultural Commodities At The West Part Of Upland Lawu
}

\author{
Puguh Karyanto a ${ }^{\text {, Rahayu }}{ }^{\mathrm{b}}$ \\ ${ }^{a}$ Pendidikan Biologi FKIP UNS, Jl Ir Sutami 36 a Surakarta, karyarina@yahoo.com \\ ${ }^{\mathrm{b}}$ Ilmu Tanah Fakultas Pertanian UNS, Jl Ir Sutami 361 Surakarta
}

\begin{abstract}
This research is about to examine the site-suitability of horticultural plantation at the west part of Lawu. The research was conducted through a survey upon the cultivated horticultural commodities by comparing their agronomic prerequisite with measured climatic conditions and land performances. The research shows that the most critical determinant for the performed horticultural cultivation is the slope of the landscape. Hence, horticultural cultivation activities must emphasize for not to ignore the importance of standing crop and slopeland's management.
\end{abstract}

Keywords: Land suitability evaluation. Horticultural commodities 